\title{
Tingkat Pemahaman dan Minat Pengurus Dewan Kemakmuran Masjid Terhadap Financial Technology (Fintech) Syariah
}

\author{
Jefriyanto $^{1 *}$, Didik Riyanto ${ }^{2)}$ \\ ${ }^{1}$ Prodi Akuntansi, STIE Mahaputra Riau, Indonesia \\ ${ }^{2}$ Prodi Akuntansi, STIE Pertiwi, Indonesia \\ *Email korespondensi: jefriinfo@gmail.com
}

\begin{abstract}
This study aims to examine the level of understanding and interest in the management of the Mosque Prosperity Council towards sharia fintech. This type of research built by the author is a quantitative descriptive study by conducting surveys. The population in this study is the Mosque Prosperity Council in Jakarta and its surroundings. The sample are the administrators of the Mosque Prosperity Council. The sampling technique used was random sampling, the sample used was 42 respondents. The results showed that the respondents had a good understanding and a high enough interest in fintech. However, for sharia fintech, respondents have less understanding and knowledge. As many as $69 \%$ of the respondents stated that they did not understand how to use the Sharia fintech, and only $9.5 \%$ of respondents understood how to use it. However, the respondents have a high enough interest in using sharia fintech in the mosque environment, as much as $52.4 \%$.
\end{abstract}

Keywords: Fintech, Financial Technology, Sharia

Saran sitasi: Jefriyanto., \& Riyanto, D. (2021). Tingkat Pemahaman dan Minat Pengurus Dewan Kemakmuran Masjid Terhadap Financial Technology (Fintech) Syariah. Jurnal Ilmiah Ekonomi Islam, 7(01), 75-80. doi:http://dx.doi.org/10.29040/jiei.v7i1.1857

\section{DOI: http://dx.doi.org/10.29040/jiei.v7i1.1857}

\section{PENDAHULUAN}

Industri fintech telah hadir di Indonesia sejak 2016 hingga saat ini. Jenis solusi fintech yang tersedia di pasar juga semakin berkembang dan bervariasi. Pada awalnya, fintech Indonesia hanya bergerak pada dua partikel yakni pembayaran digital (e-money) dan pinjaman online (peer to peer lending). Kini berkembang hingga mencakup Aggregator, innovative credit scoring, perencana keuangan, layanan urun dana (equity crowdfunding), dan project financing. Hingga akhir kuartal II tahun 2020, di antara empat kategori model bisnis tekfin, pinjaman online menjadi yang paling dominan $44 \%$, diikuti oleh tekfin kategori Inovasi Keuangan Digital (IKD) sebanyak $24 \%$, pembayaran digital $17 \%$, lalu diikuti layanan urun dana sebanyak $1 \%$. (Kontan.co.id, 2020).

Digitalisasi saat ini memungkinan sektor perbankan dan jasa keuangan syariah melakukan transformasi untuk meraih pasar yang lebih luas dan menciptakan produk praktis yang sesuai untuk kebutuhan masyarakat. Sebagai salah satu negara dengan penduduk muslim terbesar di dunia, layanan keuangan digital atau financial technology (fintech) syariah memiliki potensi pertumbuhan yang besar, terutama melalui adanya layanan investasi dan pembiayaan syariah. Fintech syariah di Indonesia diatur dan mengacu pada Fatwa Dewan Syariah Nasional Majelis Ulama Indonesia (DSN MUI) Nomor 117/2018 tentang Layanan Pembiayaan Berbasis Teknologi Informasi Berdasarkan Prinsip Syariah. (Asosiasi Fintech Indonesia, 2019).

Mengutip pemberitaan pada republika.co.id, 2019, Dewan Syariah Nasional (DSN) Majelis Ulama Indonesia (MUI) mendukung penyusunan peta jalan financial technology (fintech) syariah yang diinisiasi Komite Nasional Keuangan Syariah (KNKS). DSN merupakan lembaga yang bertanggung jawab memberi rekomendasi atau opini syariah pada fintech yang hendak mendaftar di Otoritas Jasa Keuangan (OJK). Sehingga perizinan fintech pembiayaan syariah lebih ketat daripada konvensional. Anggota 
DSN MUI yang membidangi fintech, Azharuddin Lathif menyampaikan DSN membantu mengembangkan fintech dari beberapa aspek. Pertama, dalam penerbitan fatwa terkait fintech syariah. Kedua, pemberian rekomendasi calon pengawas syariah yang akan masuk dalam perusahaan fintech syariah. Ketiga, sosialisasi, literasi, dan edukasi aspek prinsip syariah fintech di masyarakat.

Penerapan financial technology dapat dilakukan pengurus masjid untuk dapat menambah sumber pendapatan masjid. Fintech yang dapat digunakan yaitu aplikasi Bebas Bayar yang merupakan jenis fintech payment gateway. Aplikasi tersebut memungkinkan masjid untuk mendapatkan berbagai sumber pendapatan baru. Pendapatan tersebut terbagi menjadi pendapatan bisnis dan juga pendapatan donasi. Kegiatan bisnis akan menghasilkan keuntungan penjualan produk ecer dan bonus tunai tiap transaksi. Sementara itu donasi diperoleh dari transaksi yang dilakukan jamaah yang tergabung dalam jaringan bisnis akun bebas bayar masjid dan juga dari transfer langsung yang dilakukan oleh pengguna bebas bayar kepada akun masjid. (Wisando dan Indarwati, 2020).

Bank Mega Syariah bersama Masjid Istiqlal bersinergi meluncurkan aplikasi $e$-Istiqlal yang menggunakan platform DOKU Zocial Super App. EIstiqlal merupakan aplikasi berbasis komunitas, di mana fitur serta konten di dalamnya ditujukan untuk mendukung berbagai aktivitas para pengguna secara online, baik yang merupakan jamaah Masjid Istiqlal maupun masyarakat secara luas. Direktur Utama Bank Mega Syariah Yuwono Waluyo mengatakan, di tengah kondisi pandemi seperti saat ini, aplikasi ini hadir untuk memudahkan para penggunan yang tidak terbatas hanya dari kalangan jamaah Masjid Istiqlal namun juga seluruh masyarakat Indonesia untuk menikmati konten-konten Islami khas Masjid Istiqlal sekaligus menikmati kemudahan layanan digital untuk berkegiatan sehari-hari. (CNBCIndonesia.com, 2020).

Ketua Umum Dewan Masjid Indonesia (DMI), Jusuf Kalla mengatakan jumlah masjid dan mushola di Indonesia mencapai 800.000 atau terbanyak di dunia. Masjid di Indonesia ini hanya perlu didorong dan tidak perlu dijaga kepolisian, karena masingmasing umat punya rasa memiliki untuk selalu memakmurkan masjidnya (Republika.co.id, 2020). Dewan Kemakmuran Masjid (DKM), merupakan organisasi yang dikelola oleh jemaah muslim dalam melangsungkan aktivitas di masjid. Setiap masjid yang terkelola dengan baik memiliki DKM dengan strukturnya masing-masing. Secara umum, pembagian kerjanya terbagi menjadi tiga yaitu Bidang 'Idarah (administrasi manajemen masjid), Bidang 'Imarah (aktivitas memakmurkan masjid) dan Bidang Ri'ayah (pemeliharaan fisik masjid). (Wikipedia.org, 2020).

Menurut Bank Indonesia, Financial technology/fintech merupakan hasil gabungan antara jasa keuangan dengan teknologi yang akhirnya mengubah model bisnis dari konvensional menjadi moderat, yang awalnya dalam membayar harus bertatap-muka dan membawa sejumlah uang kas, kini dapat melakukan transaksi jarak jauh dengan melakukan pembayaran yang dapat dilakukan dalam hitungan detik saja. Dasar hukum penyelenggaraan fintech dalam system pembayaran di Indonesia antara lain:

a. Peraturan Bank Indonesia No. 18/40/PBI/2016 tentang Penyelenggaraan Pemrosesan Transaksi Pembayaran

b. Surat Edaran Bank Indonesia No. 18/22/DKSP perihal Penyelenggaraan Layanan Keuangan Digital

c. Peraturan Bank Indonesia No. 18/17/PBI/2016 tentang Uang Elektronik

Menurut Dorfleitner, Hornuf, Schmitt, \& Weber (2017) dalam Ansori (2019), fintech merupakan industri yang bergerak dengan sangat cepat dan dinamis dimana terdapat banyak model bisnis yang berbeda. Sedangkan menurut Hsueh (2017), Teknologi Keuangan juga disebut sebagai Fintech,merupakan model layanan keuangan baru yang dikembangkan melalui inovasi teknologi informasi.

Asosiasi Fintech Indonesia (2019), Fintech syariah di Indonesia diatur dan mengacu pada fatwa Dewan Syariah Nasional Majelis Ulama Indonesia (DSN MUI) Nomor 117/2018 tentang layanan pembiayaan berbasis teknologi informasi berdasarkan prinsip syariah. Berdasarkan fatwa tersebut, yang dimaksud dengan layanan fintech berdasarkan prinsip syariah adalah penyelenggaraan layanan jasa keuangan berdasarkan prinsip syariah yang mempertemukan atau menghubungkan pemberi pembiayaan dengan penerima pembiayaan dalam rangka melakukan akad pembiayaan melalui sistem elektronik dengan menggunakan jaringan internet.

Fatwa tentang Uang Elektronik Syariah (Fatwa No: 116/DSN-MUI/IX/2017) dan fatwa tentang 


\section{Jurnal Ilmiah Ekonomi Islam, 7(01), 2021, 77}

layanan pembiayaan berbasis teknologi informasi berdasarkan prinsip syariah (Fatwa No:117/DSNMUI/II/2018) merupakan kelompok fatwa yang terkait dengan aktivitas dan produk lembaga keuangan syariah (LKS) dan lembaga bisnis syariah (LBS). Fatwa tentang Uang Elektronik Syariah (Fatwa No: 116/DSN-MUI/IX/2017) di antaranya mengatur hubungan hukum di antara para pihak yang terlibat dalam transaksi uang elektronik dan prinsip umum yang wajib dipatuhi pada saat melakukan transaksi uang elektronik. Ditekankan dalam fatwa tersebut bahwa akad antara penerbit dengan pemegang uang elektronik adalah akad wadi' $a h$ atau akad qardh. Akad yang dapat digunakan penerbit dengan para pihak dalam penyelenggaraan uang elektronik (prinsipal, acquirer, Pedagang (merchant), penyelenggara kliring, dan penyelenggara penyelesai akhir) adalah akad ijarah, akad ju'alah, dan akad wakalah bi alujrah. Dan Akad antara penerbit dengan agen layanan keuangan digital adalah akad ijarah, akad ju'alah, dan akad wakalah bi al-ujrah. Berikutnya, penyelenggaraan dan penggunaan uang elektronik wajib terhindar dari transaksi yang ribawi, gharar, maysir, tadlis, risywah, dan israf, serta transaksi atas objek yang haram atau maksiat. Lalu, jumlah nominal uang elektronik yang ada pada penerbit harus ditempatkan di bank syariah; dan dalam hal kartu yang digunakan sebagai media uang elektronik hilang maka jumlah nominal uang yang ada di penerbit tidak boleh hilang. (Majelis Ulama Indonesia, 2018).

Sementara itu fatwa tentang Layanan Pembiayaan Berbasis Teknologi Informasi Berdasarkan Prinsip Syariah (Fatwa No:117/DSNMUI/II/2018) mengatur ketentuan umum prinsip syariah dalam kegiatan fintech dan ragam produk yang dapat dijalankan, antara lain, penyelenggaraan layanan pembiayaan berbasis teknologi informasi tidak boleh bertentangan dengan prinsip syariah, yaitu antara lain terhindar dari riba, gharar, maysir, tadlis, dharar, zhulm, dan harm. Berikutnya, akad yang digunakan oleh para pihak dalam penyelenggaraan Layanan Pembiayaan berbasis teknologi informasi dapat berupa akad-akad yang selaras dengan karakteristik layanan pembiayaan, antara lain akad albai', ijarah, mudharabah, musyarakah, wakalah bi al ujrah, dan qardh.

Ragam produk yang dapat dijalankan oleh penyelenggara layanan pembiayaan berbasis teknologi, antara lain pembiayaan anjak piutang (factoring), pembiayaan pengadaan barang pesanan pihak ketiga (Purchase Order); pembiayaan pengadaan barang untuk pelaku usaha yang berjualan secara online (online seller); Pembiayaan pengadaan barang untuk pelaku usaha yang berjualan secara online dengan pembayaran melalui penyelenggara payment gateway; Pembiayaan untuk Pegawai (Employee), dan Pembiayaan berbasis komunitas (community based) (Majelis Ulama Indonesia, 2018).

Dengan difungsikannya mesjid sebagai pusat aktivitaaas kehidupan, baik aktivitas keagamaan, sosial, maupun lainnya, akan menjadikannya sebagai wadah alternatif bagi pembangunan masyarakat. Hal ini nantinya bisa menjadi salah satu tempat untuk memecahkan masalah-masalah yang ada di masyarakat. Oleh karena itu, masjid perlu diorganisasi. Dan organisasi kemesjidan yang dikenal di masyarakat adalah DKM. Dengan peranannya yang sangat besar terhadap pengembangan masyarakat, maka DKM memiliki potensi terhadap peningkatan kesejahteraannya, yang merupakan bagian dari pemberdayaan kehidupan.

Institusi mesjid dalam memberikan makna yang utuh bagi masyarakat harus berada dalam multi guna, artinya perlu adanya pengorganisasian pengurus secara teratur dan efektif dalam meningkatkan fungsi mesjid. Dengan kata lain, bagaimana kita mengelola masjid dengan benar dan profesional. Sehingga dapat menciptakan suatu masyarakat berjamaah yang sesuai dengan keinginan Islam yaitu masyarakat yang baik, sejahtera, rukun, damai, dan berkah (Sopyan Sufri Harahap, 1996: 28)

Dewan Kemakmuran Masjid (DKM), merupakan organisasi yang dikelola oleh jemaah muslim dalam melangsungkan aktivitas di masjid. Setiap masjid yang terkelola dengan baik memiliki DKM dengan strukturnya masing-masing. Secara umum, pembagian kerjanya terbagi menjadi tiga yaitu Bidang 'Idarah (administrasi manajemen masjid), Bidang 'Imarah (aktivitas memakmurkan masjid) dan Bidang Ri'ayah (pemeliharaan fisik masjid).

Pengurus DKM atau yang biasa dikenal sebagai Takmir Masjid adalah sekelompok orang yang mempunyai kewajiban memakmurkan masjid. Hal ini sesuai dengan firman Allah S.W.T. dalam Alquran Surat At-Taubah Ayat 18: "Sesungguhnya yang memakmurkan masjid Allah hanyalah orang-orang yang beriman kepada Allah dan hari kemudian, serta (tetap) melaksanakan shalat, menunaikan zakat, dan tidak takut (kepada siapapun) kecuali kepada Allah. Maka mudah- mudahan mereka termasuk orang yang 
mendapatkan petunjuk". Pengurus dipilih dari orangorang yang memilki kelebihan dan kemampuan serta berakhlak mulia. Sehingga jamaah menghormatinya secara wajar dan bersedia membantu dan bekerja sama dalam memajukan dan memakmurkan masjid. (Dian Pratiwi, 2014).

Pengurus DKM (takmir masjid) dapat berjalan dengan baik manakala ada program kerja yang menjadi acuan kegiatan. Program kerja merupakan suatu hal yang sifatnya sangat penting dan membantu suksenya kinerja takmir. (Asadullah Al-Faruq, 2010). Secara garis besar, program kerja takmir masjid terdiri dari dua macam. Pertama, program kerja bersama atau program kerja atas nama takmir masjid, bukan perbidang. Program-program di dalam kelompok ini biasanya melibatkan berbagai bidang yang ada dalam struktur takmir masjid. Kedua, program kerja khusus atau program kerja perbidang. Program kerja perbidang merupakan prakarsa dari setiap bidang dan dikerjakan oleh bidang yang bersangkutan. Masingmasing bidang harus memiliki program kerja perbidang sesuai dengan fungsi bidangnya.

\section{METODE PENELITIAN}

Jenis penelitian yang dibangun oleh penulis adalah penelitian deskriptif kuantitatif dengan pola survey. Penelitian deskriptif berfokus pada penjelasan sistematis tentang fakta yang diperoleh saat penelitian dilakukan. Desain deskriptif digunakan jika peneliti ingin menjawab permasalahan tentang fenomena yang ada, dengan pola survey, case study, causal comparative, corelational, and development. (Abdullah, 2015:30). Populasi dalam penelitian ini merupakan Dewan Kemakmuran Masjid yang berada diwilayah Jabodetabek. Dengan sampel adalah para pengurus-pengurus Dewan Kemakmuran Masjid. Teknik pengambilan sampel yang digunakan dengan random sampling. Proses pengumpulan data, dilakukan dengan menggunakan metode survey (kuisioner) yang berbentuk formulir digital (google form). Selanjutnya data yang terkumpul akan langsung dianalisis oleh Google Form dan disajikan dalam bentuk diagram ataupun grafik.

\section{HASIL DAN PEMBAHASAN}

Pada penelitian yang dilakukan mengenai "Tingkat Pemahaman dan Minat Pengurus Dewan Kemakmuran Masjid Terhadap Fintech Syariah". Kami berhasil mengumpulkan 42 responden dari 42 masjid yang berada di wilayah Jakarta dan sekitarnya
(Bogor, Depok, Bekasi, Tangerang) yang merupakan menjadi sampel. Berdasarkan survei yang telah kami lakukan dengan menggunakan Google Form yang disebar melalui sosial media, maka dapat dilihat kategori responden. Berikut hasil survei berdasarkan kategori responden:

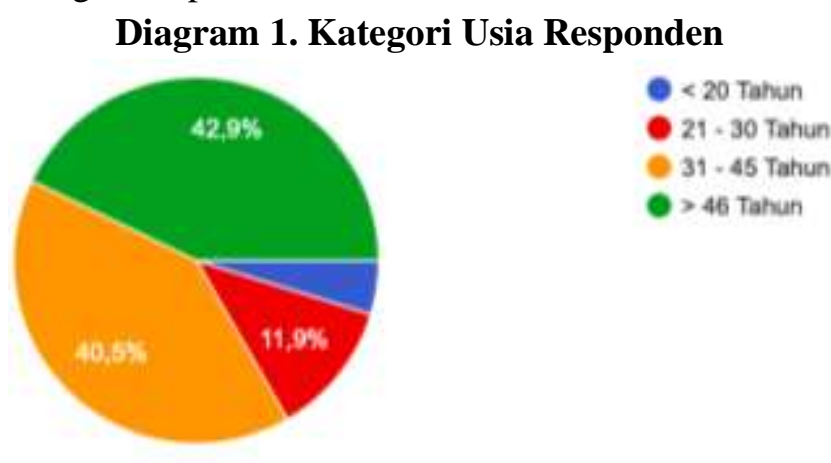

Hasil survei diatas menunjukkan bahwa, pengurus Dewan Kemakmuran Masjid (DKM) didominasi oleh orang yang berusia diatas 46 tahun $(42,9 \%)$ dan usia $31-45$ tahun $(40,5 \%)$. Sedangkan remaja atau anak muda yang berusia rentan antara 2130 Tahun sebesar $11,9 \%$ serta yang berusia dibawah 20 tahun hanya sebesar $4,8 \%$.

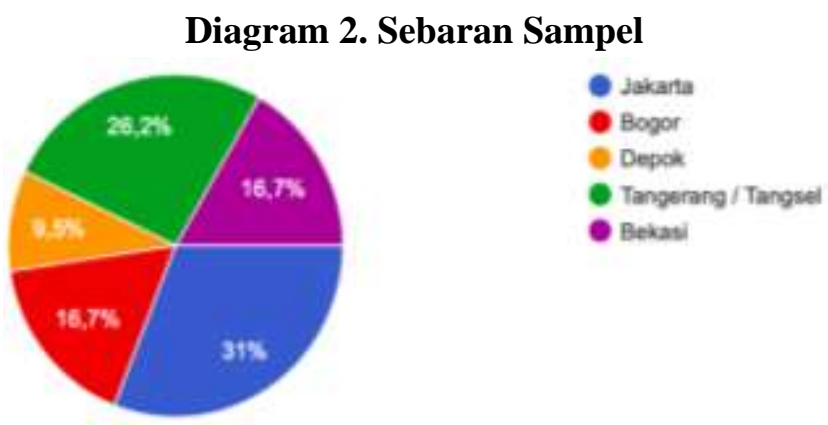

Populasi dalam penelitian ini adalah pengurus Dewan Kemakmuran Masjid (DKM) yang berada di wilayah Jakarta dan sekitarnya. Sebaran sampel seperti terlihat pada diagram 2. Sampel terbanyak di wilayah Jakarta (31\%) dan sampel terkecil di wilayah Depok.

Untuk mengetahui terkait minat dan pemahaman terhadap fintech, peneliti mencoba mencari tahu dengan memberi pertanyaan "Apakah anda memiliki aplikasi seperti Gojek, Grab, Tokopedia, Lazada, Olx, Kredivo, Dana, dan lain sebagainya?". Hasil survey menunjukan tidak semua responden memiliki aplikasi tersebut yaitu sebesar $11,9 \%$, dan sebagaian besar memang $(88,1 \%)$ sudah memiliki aplikasi tersebut. Hasil survey seperti terlihat pada gambar berikut ini: 
Jurnal Ilmiah Ekonomi Islam, 7(01), 2021, 79

Diagram 3. Kepemilikan Aplikasi Fintech

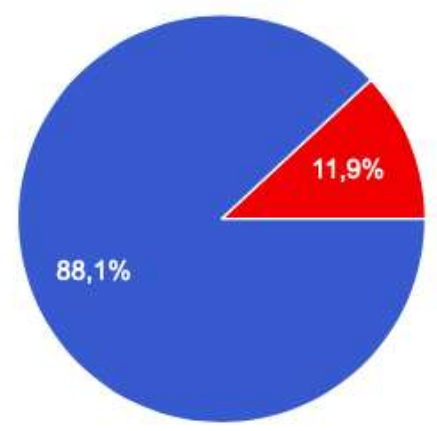

Dari survey awal diketahui, responden Sebagian besar memiliki aplikasi-aplikasi yang termasuk Fintech. Namun untuk mengetahui tingkat pemahaman dalam penggunaan aplikasi tersebut, peneliti memberi pertanyaan. Pertanyaannya adalah "Seberapa besar anda menguasai/memahami dalam menggunkan aplikasi tersebut (seperti Gojek, Grab, Tokopedia, Lazada, Olx, Kredivo, Dana, dan lain sebagainya)?". Hasil tanggapan digambarkan pada diagram berikut:

Diagram 4. Tingkat Pemahaman Penggunaan Fintech
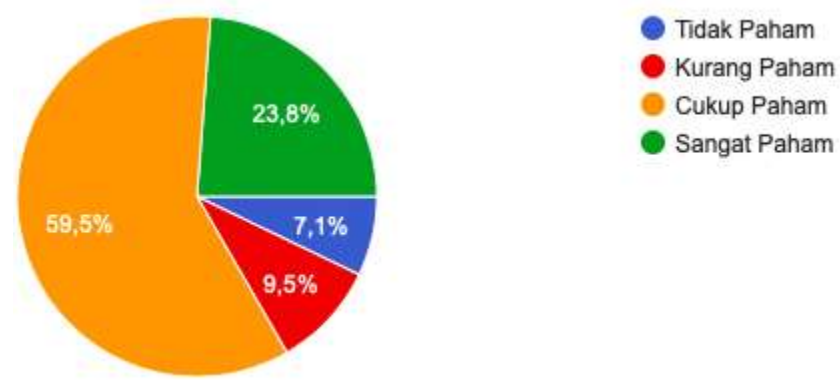

Dari diagram diatas dapat dijelaskan bahwa, responden sebagain besar memiliki pemahaman yang baik dalam menggunakan aplikasi-aplikasi tersebut (fintech). Mereka cukup mengenal dan mampu mengoperasikan aplikasi-aplikasi tersebut, hanya terdapat $7,1 \%$ yang tidak memahai. Selanjutnya terkait minat responden terhadap pemakaian fintech, peneliti mengajukan pertanyaan "Seberapa seringkah anda menggunakan aplikasi-aplikasi tersebut?". Hasil survey menunjukan, terbanyak menjawab "kadangkadang" sebesar 52,4\%. Sedangkan responden yang aktif menggukan aplikasi tersebut sebesar $48,1 \%$, terdiri dari responden tingkat penggunaan "sering" sebesar 33,3\% dan menggunakan "setiap hari" sebesar $4,8 \%$ (diagram 5). Dari data tersebut dapat dikatakan bahwa responden memiliki minat yang cukup tinggi terhadap penggunaan fintech.

\section{Diagram 5. Tingkat Pemakaian Fintech}
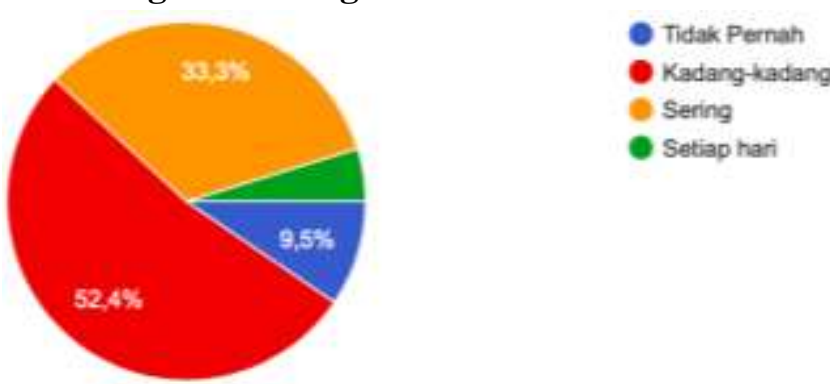

Hasil pembahasan diatas, memberikan penjelasan bahwa responden memiliki pemahaman dan minat yang tinggi terhadap fintech. Namun terkait fintech syariah, peneliti melakukan pendalaman kembali. Hasil survey menunjukan bahwa sebagian besar responden tidak mengetahui (69\%) bahkan masih ragu $(21,4 \%)$ terkait adanya fintech syariah. Hanya Sebagian kecil saja responden yang sudah mengetahui atau memahami tentang fintech syariah. Ini menjadi fakta dan tantangan bahwa responden yang merupakan pengurus Dewan Kemakmuran Masjid (DKM) memiliki pengetahuan dan pemahaman yang masih kurang terhadap fintech syariah.

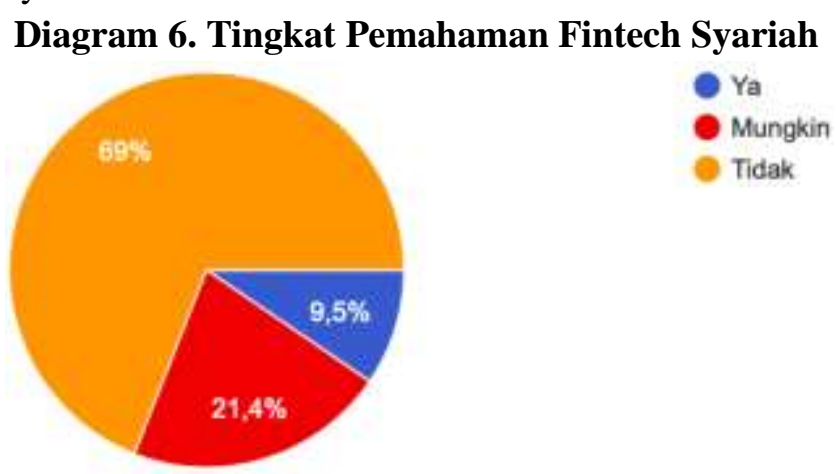

Pembahasan berikutnya adalah terkait minat responden dalam hal ini adalah para pengurus Dewan Kemakmuran Masjid (DKM) dalam menggunakan fintech syariah dilingkungan masjidnya. Hasil yang didapat cukup menarik, tidak ada responden yang menolak penggunaan fintech Syariah dilingkungan masjid mereka. Sebagian besar para responden berminat $(52,4 \%)$, namun tidak sedikit responden yang menjawab "mungkin" (47,6\%). Hal ini menunjukan terdapat responden yang masih ragu atau karena kurangnya pemahaman terhadap fintech syariah. 


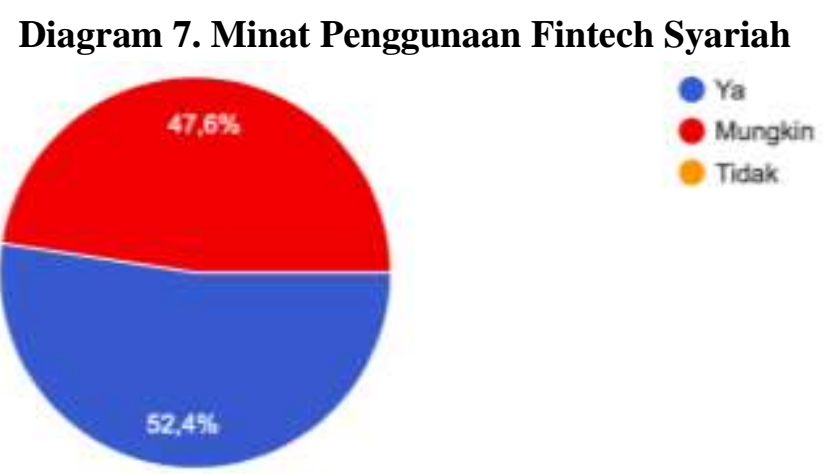

Padahal banyak manfaat yang bisa didapat dari pemanfaatan fintech syariah di lingkungan masjid. Penerapan financial technology dapat dilakukan pengurus masjid untuk dapat menambah sumber pendapatan masjid (Wisandiko dan Indarwati, 2020).

\section{KESIMPULAN}

Berdasarkan hasil dan pembahasan penelitian diatas, dapat simpulkan bahwa pengurus Dewan Kemakmuran Masjid (DKM) di wilayah Jakarta dan sekitarnya memiliki pemahaman yang baik serta minat yang cukup tinggi terhadap terhadap fintech. Sedangkan terhadap fintech syariah pengurus Dewan Kemakmuran Masjid (DKM) di wilayah Jakarta dan sekitarnya memiliki pemahaman dan pengetahuan yang kurang. Namun mereka memiliki minat yang cukup tinggi terhadap penggunaan fintech syariah di lingkungan masjid.

\section{REFERENSI}

Abdullah, Ma'ruf. 2015. Metode Penelitian Kuantitatif. Yogyakarta: Aswaja Pressindo.

Ansori, Miswan. 2019. Perkembangan dan Dampak Financial Technology (Fintech) Terhadap Industri Keuangan Syariah di Jawa Tengah. Wahana Islamika: Jurnal Studi Keislaman Vol.5 No.1 April 2019.
Burhanuddin, Chairul Iksan dan Abdi, M. Nur. 2019. Tingkat Pemahaman dan Minat Masyarakat dalam Penggunaan Fintech. Politeknik Ganesha Medan. Riset \& Jurnal Akuntansi Volume 3 Nomor 1 Februari 2019.

CNBC Indonesia. 2020. Bank Mega Syariah, Masjid Istiqlal \& DOKU Rilis e-Istiqlal.

Kontan. 2020. Mulai berkembang tahun 2016, begini kondisi fintech Indonesia hingga kuartal II-2020.

Majelis Ulama Indonesia. 2017. Fatwa Dewan Syariah Nasional - Majelis Ulama Indonesia Tentang Uang Elektronik.

Majelis Ulama Indonesia. 2017. Fatwa Dewan Syariah Nasional - Majelis Ulama Indonesia Tentang Layanan Pembiayaan Berbasis Teknologi Informasi Berdasarkan Prinsip Syariah.

Republika. 2020. Dukungan DSN dalam Pengembangan Fintech Syariah. (online) https://republika.co.id/berita/pxuy88370/dukung an-dsn-dalam-pengembangan- emfintechemsyariah.

Sekaran, Uma. 2014. Research Methods For Business Metode Penelitian Untuk Bisnis Buku 1 (Edisi 4). Jakarta: Salemba Empat.

Sekaran, Uma. 2014. Research Methods For Business Metode Penelitian Untuk Bisnis Buku 2 (Edisi 4). Jakarta: Salemba Empat.

Wisandiko, Firman A. dan Indarwati, Tias A. 2020. Inovasi Model Donasi Masjid Melalui Penerapan Financial Technology Di Era Pandemi Covid-19. Airlangga Journal of Innovation Management, Vol. 1 No. 1, June 2020. DOI:10.20473/ajim.v1i1.19523. 